'ясов но дин міку викидів шкідливих речовин від втотр нспорту в ворівському р-ні, визн чено з в нт женість вулиць м. воров втомобільним тр нспортом, розр хов но коефіцієнт концентр ції н окремих ділянк х втом гістр лей м. воров , скл дено к рту інтенсивності з бруднення м. воров викид ми

лючові слов : тмосферне повітря, пересувні джерел , з бруднюв льн речовин, викиди, монооксид к рбону.

кл д тмосферного повітря - один з н йв жливіших, життєво необхідних екологічних чинників, від якого з леж ть колообіги хімічних елементів, життєдіяльність живих орг нізмів, функціонув ння біосфери. бруднення тмосферного повітря, особливо в приземному ш рі, ерозолями т г зоподібними сполук ми нег тивно вплив є н здоров'я людей, рослинний і тв ринний світ.

ід з брудненням тмосферного повітря розуміють зміну його скл ду і вл стивостей ун слідок н дходження бо утворення в ньому фізичних, біологічних чинників і хімічних сполук, що можуть несприятливо вплив ти н здоров'я людей і ст н н вколишнього природного середовищ [1]. озрізняють ст ціон рні т пересувні джерел впливу н довкілля. окрем , н втотр нспорт прип д є 34 \% від з г льної кількості викидів [3].

ід ч с роботи втомобільних двигунів внутрішнього згор ння джерел ми викидів шкідливих речовин $є$ відпр цьов ні т к ртерні г зи, т кож вип ровув ння з системи живлення. еред відпр цьов них г зів виділяють монооксид к рбону, вуглеводні, оксиди нітрогену, сполуки сульфуру, тверді ч стинки, к нцерогенні речовини [3].

икиди від пересувних джерел, з д ними підр хунків спеці лістів ержупр вління охорони н вколишнього природного середовищ в ьвівській обл., постійно збільшуються. ідбув ється це вн слідок збільшення кількості і погіршення технічного ст ну втомобільного п рку, нез довільну якість п льного, відст в ння темпів розвитку вулично-шляхової мережі тощо.

ому кту льність н лізу впливу пересувних джерел н якість тмосферного повітря в ворівському р-ні, і м. ворові зокрем , не виклик є сумнівів.

ідносини в г лузі охорони тмосферного повітря обумовлені коном кр їни “р ро охорону тмосферного повітря” від 16.10.92, № 2708-XII зі змін ми від 16.06.2011, № 3530-VI; коном кр їни “ ро охорону н вколишнього природного середовищ ” від 26.09.91, № 1264-XII зі змін ми від 16.06.2011, № 3530-VI; коном

(C) етровськ ., плун ., 2012 
кр їни “ ро з безпечення с ніт рного т епідемічного бл гополуччя н селення” від 24.02.94, № 4004-XII зі змін ми від 17.02.2011, № 3530-VI; ерж вними с ніт рними пр вил ми охорони тмосферного повітря н селених місць (від з бруднення хімічними т біологічними речовин ми) від 09.07.97, № 201 т іншими норм тивно-пр вовими КТ ми.

плив пересувних джерел н якість тмосферного повітря про н лізов но в пр цях ськін , . ськіної, . енисов , . х рової, . ніл , . ліферчук , . влової, . ог лев , . ворської т ін. [3-8, 10].

роблем з бруднення тмосферного повітря пересувними джерел ми н йгостріше стоїть у меж х густоз селених, промислово розвинених регіонів, до яких н лежить ворівський р-н і м. ворів зокрем . огляду н це ми пост вили з вд ння з'ясув ти дин міку викидів шкідливих речовин від втотр нспорту в ворівському р-ні, визн чити $з$ в нт женість вулиць м. воров втомобільним тр нспортом, розр хув ти коефіцієнт концентр ції $\mathrm{H}$ окремих ділянк х втом гістр лей м. воров , скл сти к рту інтенсивності з бруднення м. воров викид ми

онцентр цію монооксиду к рбону оцінюв ли з т кою формулою [2]:

$\mathrm{K}_{\mathrm{CO}}=\left(A+0,01 N K_{m}\right) \quad K \quad K_{h} \quad K_{c} \quad K_{b} K_{n}$,

де - фонове 3 бруднення тмосферного повітря $\left(=0,5 \mathrm{мг} / \mathrm{M}^{3}\right) ; N-$ сум рн інтенсивність руху втомобілів н ділянці вулиці (шт./год); $K_{m}$ - коефіцієнт токсичності втомобілів 3 викид ми в повітря ; $K$ - коефіцієнт, що вр ховує ер цію місцевості; $K_{h}, K_{c}, K_{b}$ - коефіцієнти, що вр ховують зміну з бруднення тмосферного повітря монооксидом к рбону з лежно від поздовжнього н хилу, швидкості вітру т вологості повітря, відповідно; $K_{n}$ - коефіцієнт збільшення з брудненості тмосферного повітря монооксидом к рбону біля перехресть.

ост нні роки н території ворівського р-ну зн чно збільшилися пок зники викидів шкідливих речовин від втотр нспорту (рис. 1). 2001 по 2005 рр. обсяги викидів колив лись у меж х 2812,0 - 2 495,7 тис. т, в 2005-2008 pp. простежено різке збільшення викидів: $з 2$ 495,7 (2005) до 5537 тис. т (2008).

сновними з бруднюв льними речовин ми у викид $\mathrm{x}$ втотр нспорту є монооксид к рбону, оксиди нітрогену, с ж, діоксид сульфуру, з них н йбільшу ч стку ст новить монооксид к рбону (78 \%), н йменшу - діоксид сульфуру (рис. 2).

кщо порівнюв ти обсяги викидів окремих шкідливих речовин (рис. 3) 3 період 2005-2008 рр., то помітн тенденція до збільшення викидів монооксиду к рбону: у 2005 р. в тмосферу їх потр пило 1952 т, в 2008 р. -4 170 т.

роте помітно зменшилися викиди вуглеводнів (у 2005 р. - 306 т, у 2008 р. - 18 т) т оксидів нітрогену (у 2005 р. - 199 т, у 2008 р. - 4 т).

и т кож визн чили 3 в нт женість ділянок вулиць м. воров втомобільним тр нспортом. ля цього виміряно інтенсивність руху втотр нспорту н території м. воров ьвівської обл. у серпні 2009 р., тр вні, серпні, вересні 2010 р. т січні 2011 р. имірюв ння виконув ли н трьох вулицях з різною інтенсивністю руху втотр нспорту ( евченк, ьвівськ, ковея).

езульт ти досліджень н в нт ження н вул. евченк, ьвівській т ковея н ведено, відповідно, у т бл. 1-3. ерш цифр - д ні спостережень 3 серпень 2009 р., друг - 3 тр вень, третя - 3 серпень, четверт - 3 вересень 2010 р. і п’ят - 3 січень 2011 p. 


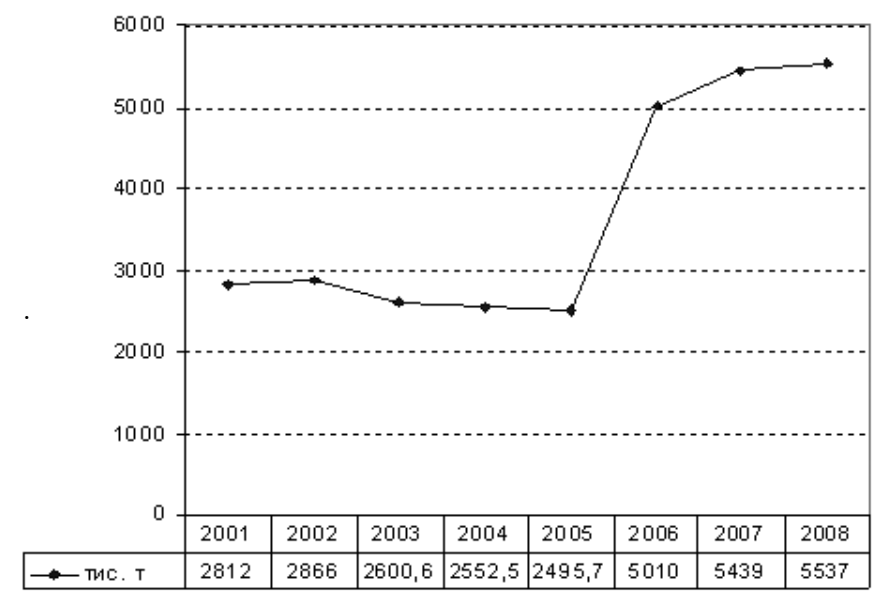

ik

ис. 1. икиди шкідливих речовин в тмосферне повітря від втотр нспорту н території ворівського р-ну. кл дено з [9].

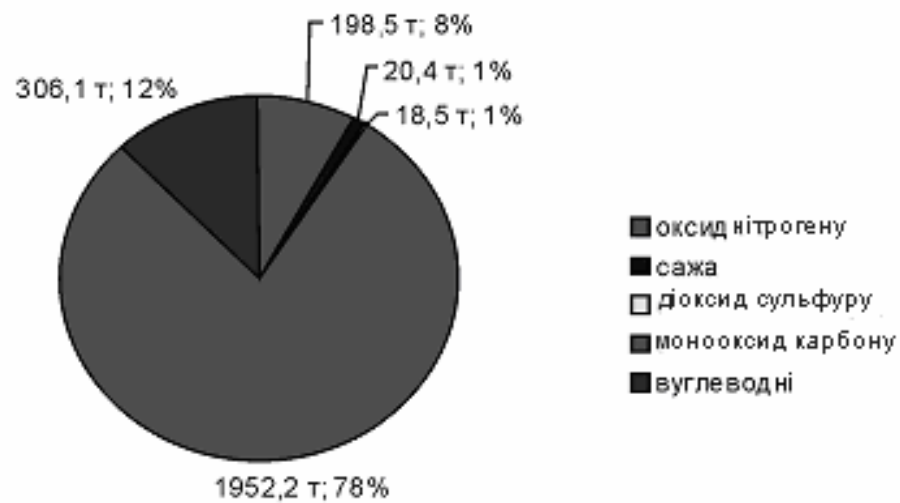

ис. 2. икиди окремих шкідливих речовин в тмосферне повітря від втотр нспорту у 2008 р. кл дено 3 [9].

т бл. 4 н ведено результ ти розр хунків коефіцієнтів концентр ції, перш цифр - д ні з серпень 2009 р., друг - 3 тр вень, третя - 3 серпень, четверт - 3 вересень 2010 р., п’ят - 3 січень 2011 р.

к б чимо, н йбільший коефіцієнт концентр ції $\mathrm{x}$ р ктерний для вул. ковея (див. т бл. 4), що зумовлено н йінтенсивнішим рухом втотр нспорту (див. т бл. 3 ).

кож помітно, що інтенсивність руху втотр нспорту в різний період дня неодн ков : н йбільш кількість тр нспорту з фіксов н в обідній ч с. підст ві порівняння кількості втотр нспорту у з зн чені періоди і коефіцієнтів концентр ції простежено незн чну тенденцію до збільшення з бруднення повітря. кщо порівнюв ти обчислені коефіцієнти концентр ції , то помітно, що в жливу роль у їхній зміні відігр ють не лише кількість втотр нспорту, й природні чинники, н прикл д, вологість повітря і 
швидкість вітру. окрем , у серпні 2009 р. в точці спостереження н вул. евченк в період $8^{00}-8^{20}$ з фіксов но 45 тр нспортних 3 собів, розр хов ний коефіцієнт концентр ції ст новить 7,1. езв ж ючи н те, що у вересні 2010 р. $з$ реєстров но більшу кількість втотр нспорту - 99, коефіцієнт концентр ції є меншим - 5. е пояснюють різною швидкістю вітру: чим більш швидкість вітру - тим менший коефіцієнт концентр ції - кщо ж порівнюв ти коефіцієнти концентр ції н різних вулицях, то їхня різниця зумовлен різною з в нт женістю втотр нспортом т поздовжніми ухил ми.

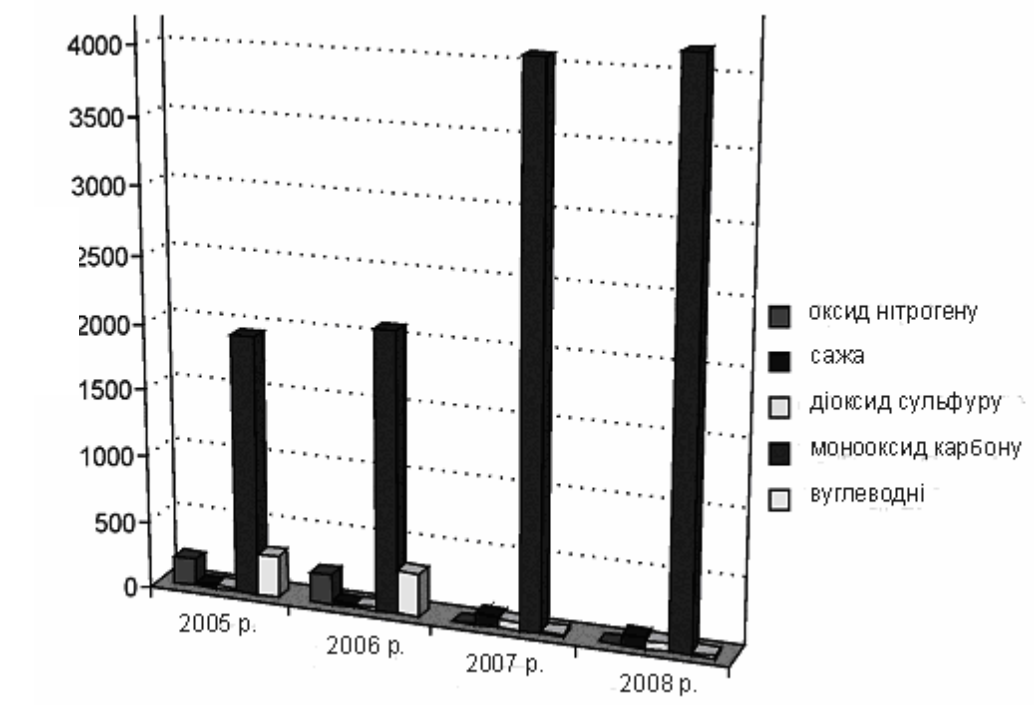

ис. 3. икиди окремих шкідливих речовин в тмосферне повітря від втотр нспорту. кл дено 3 [9].

блиця 1

втотр нспортне н в нт ження н вул. евченк (м. ворів)

\begin{tabular}{|c|c|c|c|c|c|c|}
\hline \multirow{3}{*}{$\begin{array}{c}\text { ид } \\
\text { тр нспорту }\end{array}$} & \multicolumn{6}{|c|}{ с вимірюв нь } \\
\hline & \multicolumn{2}{|c|}{$8^{00}-8^{20}$} & \multicolumn{2}{|c|}{$13^{00}-13^{20}$} & \multicolumn{2}{|c|}{$18^{00}-18^{20}$} \\
\hline & одиниць & $\%$ & одиниць & $\%$ & одиниць & $\%$ \\
\hline $\begin{array}{c}\text { егкові } \\
\text { втомобілі }\end{array}$ & $\begin{array}{l}35 / 30 / \\
73 / 78 / 88\end{array}$ & $\begin{array}{l}78 / 67 / \\
80 / 79 / 81\end{array}$ & $\begin{array}{l}63 / 46 / \\
79 / 80 / 94\end{array}$ & $\begin{array}{l}93 / 74 / \\
79 / 77 / 84\end{array}$ & $\begin{array}{l}36 / 32 / \\
38 / 40 / 45\end{array}$ & $\begin{array}{l}78 / 71 / \\
86 / 82 / 85\end{array}$ \\
\hline $\begin{array}{c}\text { ршрутні } \\
\text { мікро втобуси }\end{array}$ & $\begin{array}{l}6 / 8 / \\
14 / 17 / 16\end{array}$ & $\begin{array}{l}13 / 17 / \\
16 / 17 / 15\end{array}$ & $\begin{array}{l}4 / 12 / \\
17 / 17 / 9\end{array}$ & $\begin{array}{l}6 / 19 / \\
17 / 16 / 8\end{array}$ & $7 / 9 / 5 / 7 / 6$ & $\begin{array}{l}15 / 20 / \\
12 / 14 / 11\end{array}$ \\
\hline втобуси & $1 / 3 / 1 / 2 / 3$ & $2 / 7 / 1 / 2 / 3$ & $0 / 0 / 1 / 4 / 5$ & $0 / 0 / 1 / 4 / 4$ & $1 / 2 / 1 / 1 / 1$ & $2 / 4 / 2 / 2 / 2$ \\
\hline $\begin{array}{l}\text { нт жні } \\
\text { м шини }\end{array}$ & $3 / 4 / 3 / 2 / 2$ & $7 / 9 / 3 / 2 / 1$ & $1 / 4 / 3 / 3 / 4$ & $1 / 7 / 3 / 3 / 4$ & $2 / 2 / 0 / 1 / 1$ & $5 / 5 / 0 / 2 / 2$ \\
\hline сього & $\begin{array}{l}45 / 45 / \\
91 / 99 / 109\end{array}$ & 100 & $\begin{array}{l}68 / 62 / \\
100 / 104 / 112\end{array}$ & 100 & $\begin{array}{l}46 / 45 / \\
44 / 49 / 53\end{array}$ & 100 \\
\hline
\end{tabular}


втотр нспортне н в нт ження н вул. ьвівський (м. ворів)

\begin{tabular}{|c|c|c|c|c|c|c|}
\hline \multirow{3}{*}{$\begin{array}{c}\text { ид } \\
\text { тр нспорту }\end{array}$} & \multicolumn{6}{|c|}{ с вимірюв нь } \\
\hline & \multicolumn{2}{|c|}{$8^{00}-8^{20}$} & \multicolumn{2}{|c|}{$13^{00}-13^{20}$} & \multicolumn{2}{|c|}{$18^{00}-18^{20}$} \\
\hline & одиниць & $\%$ & одиниць & $\%$ & одиниць & $\%$ \\
\hline $\begin{array}{c}\text { егкові } \\
\text { втомобілі }\end{array}$ & $\begin{array}{l}45 / 100 / \\
93 / 95 / 98\end{array}$ & $\begin{array}{l}75 / 84 / \\
84 / 83 / 82\end{array}$ & $\begin{array}{l}\text { 64/44/ } \\
73 / 97 / 66\end{array}$ & $\begin{array}{l}89 / 79 / \\
86 / 87 / 79\end{array}$ & $\begin{array}{l}39 / 58 / \\
32 / 32 / 30\end{array}$ & $\begin{array}{l}\text { 83/91/ } \\
71 / 84 / 73\end{array}$ \\
\hline $\begin{array}{c}\text { ршрутні } \\
\text { мікро втобуси }\end{array}$ & $\begin{array}{l}11 / 12 / \\
13 / 16 / 17\end{array}$ & $\begin{array}{l}18 / 10 / \\
12 / 14 / 14\end{array}$ & $\begin{array}{l}7 / 4 / 7 / \\
11 / 15\end{array}$ & $\begin{array}{l}10 / 7 / \\
8 / 10 / 18\end{array}$ & $7 / 4 / 9 / 3 / 6$ & $\begin{array}{l}15 / 6 / 20 / \\
8 / 15\end{array}$ \\
\hline втобуси & $3 / 6 / 2 / 2 / 3$ & $5 / 5 / 2 / 2 / 3$ & $1 / 3 / 3 / 2 / 2$ & $1 / 5 / 4 / 2 / 2$ & $1 / 1 / 4 / 3 / 4$ & $\begin{array}{l}2 / 1 / 9 / 8 / 1 \\
0\end{array}$ \\
\hline $\begin{array}{l}\text { нт жні } \\
\text { м шини }\end{array}$ & $1 / 1 / 2 / 1 / 1$ & $2 / 1 / 2 / 1 / 1$ & $0 / 5 / 2 / 1 / 1$ & $0 / 9 / 2 / 1 / 1$ & $0 / 1 / 0 / 0 / 1$ & $0 / 2 / 0 / 0 / 2$ \\
\hline сього & $\begin{array}{l}60 / 119 / 110 / \\
114 / 119\end{array}$ & 100 & $\begin{array}{l}72 / 56 / 85 / \\
111 / 84\end{array}$ & 100 & $\begin{array}{l}\text { 47/64/45/ } \\
38 / 41\end{array}$ & 100 \\
\hline
\end{tabular}

блиця 3

втотр нспортне н в нт ження н вул. ковея (м. ворів)

\begin{tabular}{|c|c|c|c|c|c|c|}
\hline \multirow{3}{*}{$\begin{array}{c}\text { ид } \\
\text { тр нспорту }\end{array}$} & \multicolumn{6}{|c|}{ с вимірюв нь } \\
\hline & \multicolumn{2}{|c|}{$8^{00}-8^{20}$} & \multicolumn{2}{|c|}{$13^{00}-13^{20}$} & \multicolumn{2}{|c|}{$18^{00}-18^{20}$} \\
\hline & одиниць & $\%$ & одиниць & $\%$ & одиниць & $\%$ \\
\hline $\begin{array}{c}\text { егкові } \\
\text { втомобілі }\end{array}$ & $\begin{array}{l}117 / 120 / 140 / \\
139 / 142\end{array}$ & $\begin{array}{l}78 / 79 / \\
89 / 84 / 85\end{array}$ & $\begin{array}{l}127 / 108 / 147 / \\
140 / 176\end{array}$ & $\begin{array}{l}78 / 73 / \\
79 / \\
81 / 83 \\
\end{array}$ & $\begin{array}{l}126 / 120 / \\
102 / 106 / \\
110\end{array}$ & $\begin{array}{l}81 / 82 / \\
77 / 77 / 70\end{array}$ \\
\hline $\begin{array}{l}\text { ршрутні } \\
\text { мікро вто- } \\
\text { буси }\end{array}$ & $\begin{array}{l}22 / 19 / \\
15 / 16 / 17\end{array}$ & $\begin{array}{l}\text { 15/13/ } \\
9 / 10 / 10\end{array}$ & $\begin{array}{l}20 / 19 / \\
21 / 22 / 19\end{array}$ & $\begin{array}{l}12 / 13 / \\
12 / 11 / 9\end{array}$ & $12 / 10 / 16 / 15 / 18$ & $\begin{array}{l}8 / 7 / \\
12 / 11 / 13\end{array}$ \\
\hline втобуси & $7 / 8 / 3 / 6 / 4$ & $5 / 5 / 2 / 4 / 2$ & $\begin{array}{l}9 / 12 / 13 / 10 / \\
10\end{array}$ & $6 / 8 / 7 / 6 / 5$ & $\begin{array}{l}9 / 4 / 11 / 12 / \\
10\end{array}$ & $6 / 3 / 8 / 9 / 7$ \\
\hline $\begin{array}{c}\text { нт жні } \\
\text { м шини }\end{array}$ & $3 / 5 / 0 / 4 / 5$ & $2 / 3 / 0 / 2 / 3$ & $6 / 8 / 4 / 4 / 8$ & $4 / 6 / 2 / 2 / 3$ & $8 / 13 / 4 / 4 / 5$ & $5 / 8 / 3 / 3 / 3$ \\
\hline сього & $\begin{array}{l}149 / 152 / \\
158 / 165 / \\
168\end{array}$ & 100 & $\begin{array}{l}162 / 147 / \\
185 / 176 / \\
213\end{array}$ & 100 & $\begin{array}{l}155 / 147 / \\
133 / 137 / \\
143\end{array}$ & 100 \\
\hline
\end{tabular}

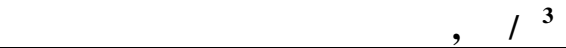

блиця 4

\begin{tabular}{|c|c|c|c|}
\hline \multirow{2}{*}{ улиця } & \multicolumn{3}{|c|}{ с вимірюв нь } \\
\cline { 2 - 4 } & $8^{00}$ & $13^{00}$ & $18^{00}$ \\
\hline евченк & $7,1 / 8,3 / 9,2 / 5,0 / 13,3$ & $9,7 / 10,5 / 10,0 / 5,1 / 13,7$ & $7,2 / 8,3 / 5,2 / 2,8 / 7,4$ \\
& & & $2,9 / 3,9 / 2,6 / 1,3 / 3,3$ \\
\hline ьвівськ & $3,5 / 6,6 / 5,8 / 3,0 / 7,8$ & $4,1 / 3,5 / 4,7 / 2,9 / 5,8$ & \\
\hline ковея & $14,5 / 11,6 / 13,0 / 5,9 / 15,0$ & $15,6 / 11,3 / 15,0 / 6,2 / 18,6$ & $15,0 / 11,3 / 11,2 / 5,0 / 12,9$ \\
\hline
\end{tabular}

кщо х р ктеризув ти з бруднення викид ми втотр нспорту різних ділянок м. ворів (рис. 4), то н йвищ концентр ція н вул. ковея т об'їзній дорозі, що зумовлено розміщенням н вул. ковея втост нції, т кож інтенсивним рухом вто- 
тр нспорту до укр їнсько-польського кордону. оефіцієнт концентр ції риторії ст новить 3,35 мг/м³ і вище. д ними моделюв ння, н йменше з бруднення спостеріг ємо в р йоні вул. исливської т уряви (коефіцієнт концентр ції ст -

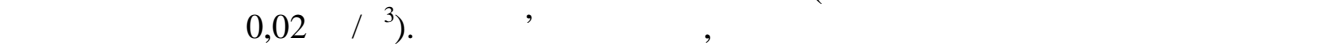
міст й інтенсивність руху тр нспорту тут незн чн . ля центр льної ч стини міст

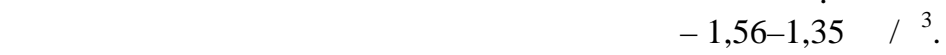
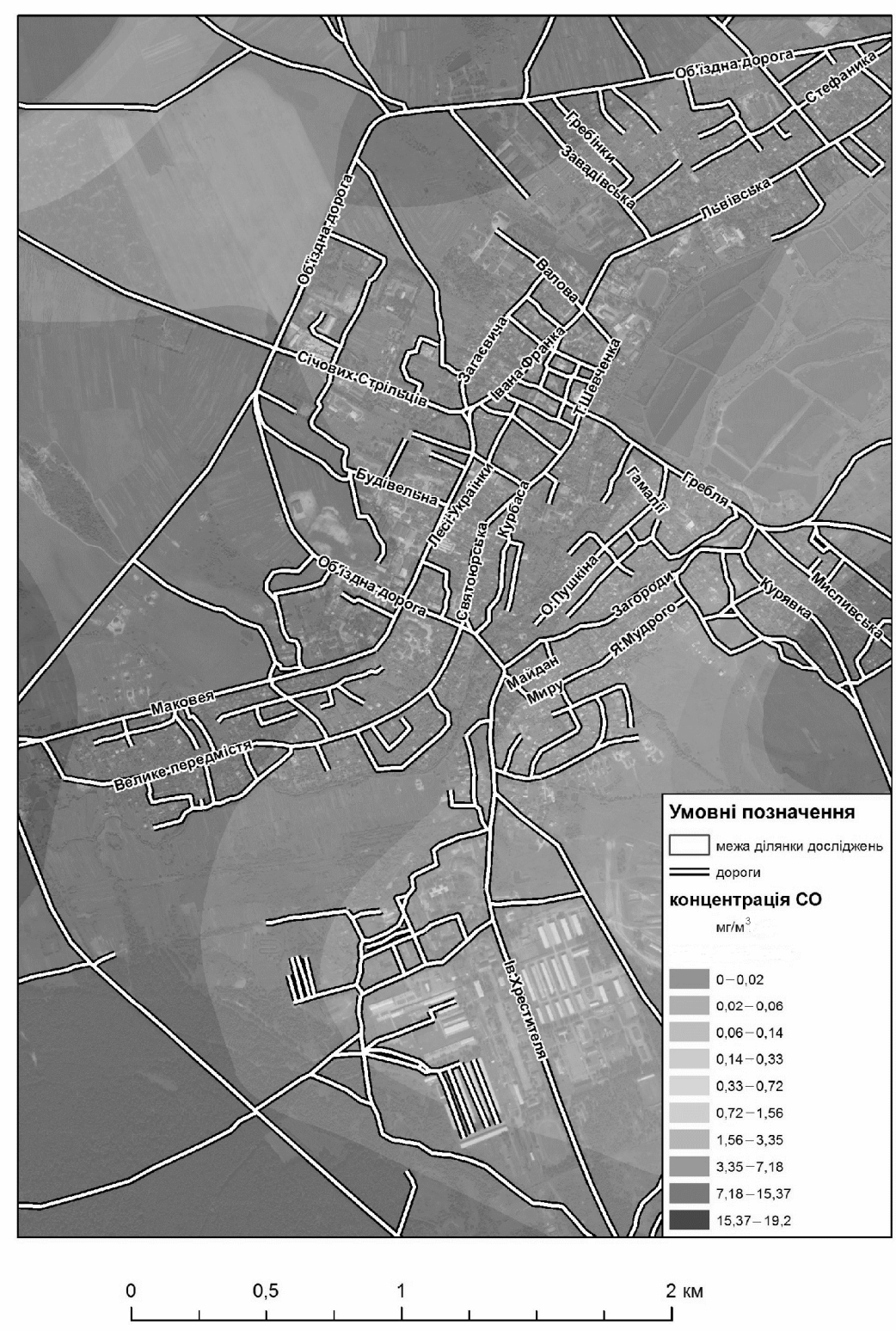

ис. 4. рт інтенсивності з бруднення м. ворів викид ми 
тож, з'ясов но, що ост нніми рок ми н території ворівського р-ну зн чно збільшилися пок зники викидів шкідливих речовин від втотр нспорту, с ме: у 2001 р. їхній обсяг ст новив 2812 тис. т, 2008 р. зріс до 5537 тис. т.

сновними з бруднюв льними речовин ми у викид х втотр нспорту є монооксид к рбону, оксиди нітрогену, с ж , діоксид сульфуру, з них н йбільшу ч стку ст новить монооксид к рбону - 78 \%, н йменшу - діоксид сульфуру.

ході з'ясув ння інтенсивності руху втотр нспорту н трьох вулицях воров ( евченк, ьвівськ , ковея) визн чено, що н йінтенсивнішим є рух н вул. ковея, це зумовлено пересув нням втотр нспорту до укр їнсько-польського кордону т розміщенням втост нції.

одо коефіцієнт концентр ції , то н йвищий його пок зник простежено н вул. ковея т об'їзній дорозі (3,35 мг/м³ і вище). д ними моделюв ння н йменше з бруднення спостережено в р йоні вулиць исливської т уряви $\left(0,02 \mathrm{mг} / \mathrm{m}^{3}\right)$, середні

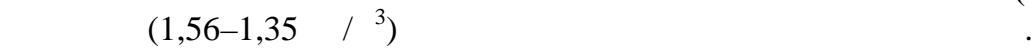

1. кон кр їни “ ро охорону тмосферного повітря” від 16.10.1992 p. № 2708-XII зі змін ми від 16.06.2011, N 3530-VI. ежим достопу до джерел : zakon.rada.gov.ua. - 15 c.

2. ілявський . . снови екології: теорія т пр ктикум : н вч. посібник / . . ілявський, . . утченко, . . вроцький. - . : ібр , 2002. -352 c.

3. ськін .. . н ліз дин міки з бруднення тмосферного повітря кр їни викид ми втотр нспорту / . . ськін, . . ськін // існ. ременчуцького держ. політехн. ун-ту ім. . строгр дського. - 2009. - ип. 5 (58). - . 1. - . 109-112.

4. енисов . ., ог лев . . роблемы экологиз ции втомобильного тр нспорт : изд. 2-е. / . . енисов, . ог лев. - б.: ,2004.-312 с.

5. $x$ ров . . н ліз впливу втотр нспортун н тмосферне повітря / нформ тик т комп'ютерні технології 2007 / . . х ров // тері ли III н ук.-техн. конф. молодих вчених т студентів. - онецьк, 2007. - .77-78.

6. ніло . . втомобіль т н вколишнє середовище / . . ніло, . . ей, . . овенський. . : p пор, 2000. $-304 \mathrm{c}$.

7. ліферчук . . плив з бруднення тмосферного повітря викид ми втотр нспорту н ст н здоров'я школярів міст ьвов / . . ліферчук, . . окот, . . рник, . . м нець // ук. вісн. кр. держ. лісотехн. ун-ту. - 2003. - ип. 13.5. - . 125-130.

8. влов . . кология тр нспорт : учебник для вузов / . . влов . - . : р нспорт, 2000. $-248 \mathrm{c}$.

9. т тистичний збірник ьвівщини / з ред. . . тковського. - ьвів, 2006. - 100 с.; 2009. $100 \mathrm{c}$.

10. ворськ . . т тистичний н ліз якості тмосферного повітря в кр їні // зб. н ук.-техн. пр ць ц. лісотехн. ун-ту кр їни / . . ворськ , . . конніков. $-2010 .-$ ип. 20. - .83-88. 


\title{
ANALYSIS OF THE INFLUENCE OF MOTOR TRANSPORT ON THE OUTDOOR AIR POLLUTION OF THE TOWN OF YAWORIV BY CARBON MONOXIDE
}

\author{
M. Petrovska, L. Kaplun
}

Ivan Franko National University of Lviv, . Doroshenko St., 41, UA - 79000 Lviv, Ukraine

The dynamics of the harmful substances emissions from the motor transport in Yaworiv region has been determined as well as the traffic density on the streets of Yaworiv town. The coefficient of CO concentration on some highway strips has been calculated. The map of the intensity of the pollution from CO emissions in Yaworiv has been composed.

Key words: atmospheric air, moving pollution sources, polluting sources, emissions, carbon monoxide.

- етровск я, . плун

ьвовский н иион льный университет имени в н р нко,

ул. . орошенко, 41, г. ввов, 79000, кр ин

ыяснено дин мику выбросов вредных веществ от втотр нспорт в воровском р-не, определено з груженность улиц г. воров втомобильным тр нспортом, р ссчит но коэффициент концентр ции н отдельных уч стк х втом гистр лей воров , сост влено к рту интенсивности з грязнения город выброс ми

лючевые слов : тмосферный воздух, подвижные источники, з грязняющие веществ , выбросы, монооксид к рбон . 